\title{
GRK1 wt Allele
}

National Cancer Institute

\section{Source}

National Cancer Institute. GRK1 wt Allele. NCI Thesaurus. Code C51307.

Human GRK1 wild-type allele is located within 13q34 and is approximately 4 kb in length.

This allele, which encodes rhodopsin kinase protein, plays a role in the deactivation of rhodopsin. Heritable defects in the GRK1 gene cause Oguchi disease 2. 